\title{
Assessment of Variability and Character Association in Pearl Millet [Pennisetum glaucum (L.) R.Br.]
}

\author{
R. Annamalai ${ }^{1 *}$, N. Aananthi ${ }^{1}$, M. Arumugam Pillai ${ }^{1}$ and D. Leninraja ${ }^{2}$ \\ ${ }^{I}$ Department of Plant Breeding and Genetics, Agricultural College and Research Institute, \\ Killikulam, Tamil Nadu, India \\ ${ }^{2}$ Department of Soil Science and Agricultural Chemistry, Agricultural College and Research \\ Institute, Killikulam, Tamil Nadu, India \\ *Corresponding author
}

\section{A B S T R A C T}

The present investigation was carried out to study the genetic variability parameters and character association in fifty pearl millet genotypes for

\section{Keywords}

Pearl millet, Grain yield, Genetic variability,

Correlation coefficient, Path analysis

Article Info

Accepted:

21 May 2020

Available Online:

10 June 2020 thirteen different biometrical traits. A wide range was observed for all parameters of genetic variability for all the traits. The traits like grain yield, seed weight per spike, number of productive tillers, flag leaf area, number of nodes per plant showed greatest variability and considered highly variable compared to other biometrical traits. Character association studies revealed that grain yield was highly significant and positively correlated with seed weight per spike (0.70), spike length (0.69), 1000 grain weight (0.56), number of productive tillers (0.53), number of tillers per plant (0.49) and peduncle length (0.42). Highest direct effect on grain yield was contributed by the number of productive tillers per plant and seed weight per spike. Number of nodes per plant and number of tillers per plant showed high positive and indirect effect on grain yield through number of productive tillers. Hence, these traits were regarded as significant attributes in devising selection criteria for attaining yield objectives.

\section{Introduction}

Pearl millet [Pennisetum glaucum (L) R.Br], $2 \mathrm{n}=14$, is an annual $\mathrm{C}_{4}$ coarse grained crop, ranked as the sixth most important global cereal crop widely cultivated by the resource poor farmers in arid and semi-arid regions of Africa and the Indian subcontinent
(Srivastava et al., 2019). It can thrive under adverse conditions like drought, salinity low rainfall and fertility (Kumawat et al., 2019). It has higher potential for biomass production, multiple forage crop characteristics such as rapid regeneration efficiency, high tillering capacity, more leaf area, and greater green fodder yield and pest and disease tolerant. 
Pearl millet remains as the major source of nutritious food for poorest people in semi-arid regions of tropical and sub-tropical countries. It is the staple food grain with a high nutritional value and is also used as a feed, fodder, construction material and even its potential as a source of bio-fuel (Singh and Chhabra, 2018). In India, it is grown in an area of 7.4 million hectares with 9.13 million tonnes of production and a productivity of $1237 \mathrm{~kg} / \mathrm{ha}$ (Directorate of millets Development). Pearl millet grains are rich in calories, proteins (6-15\%), fat (5-6\%), carbohydrates(60-72\%), fibre (1-1.8\%), vitamins, minerals and less amount of antinutritional factors like HCN, Phytic acid which makes it highly nutritive and palatable crop in comparison with other crops (Sharma et al., 2018). Grain yield variability can be correlated with number of filled grains per spike and grain weight per spike are determined by genotype, environmental factors like temperature, soil and nutritional factors and availability of water (Ullah et al., 2018). Improved grain yield of pearl millet depends upon contribution of the biometrical traits. The system for crop enhancement needs knowledge on genetic variability, interaction between yield and yield contributing traits. The main aim of plant breeding programmes is improvement of productivity which is measured in terms of yield per unit area. The complex nature of yield is associated with yield contributing traits which are interrelated among them. The nature and degree of the yield correlated with other characters allows to predict the relative influence of individual character on yield improvement thereby enable the breeders to identify desirable traits that play a pivotal role in yield improvement. Path analysis gives impact of each contributing characters to yield directly as well as indirectly and also helps the breeders to rate the genetic traits according their contribution. The objective of the present study was to assess genetic variability for yield and related traits and to compare the correlations of the characters on grain yield present in the diverse pearl millet genotypes for the different characters.

\section{Materials and Methods}

The experimental material consisted of 50 pearl millet genotypes collected from ICRISAT, Hyderabad. The field trial was conducted at Farm premises of Agricultural College and Research Institute, Killikulam during Kharif 2018.The details of the genotypes are given in Table 1.

The experiment was carried out in Randomized Block Design and replicated twice. The seeds of 50 pearl millet genotypes were directly sown in field adopting a spacing of $45 \times 15 \mathrm{~cm}$. Each genotype represented by six rows of each six m length with $45 \mathrm{~cm}$ between rows and $15 \mathrm{~cm}$ between plants. Appropriate agronomic practices were followed to raise a good crop. The Observations were recorded at various growth stage of pearl millet on ten randomly selected plants for economically important biometrical traits viz., grain yield, flag leaf area, number of nodes per plant, peduncle length, seed weight per spike, number of productive tillers, number of tillers per plant, spike length, 1000 grain weight, flag leaf length, flag leaf width, plant height, days to $50 \%$ flowering. The mean values of individual genotypes were subjected to statistical analysis using statistical software's GENRES, Meta R and R studio software's.

\section{Results and Discussion}

\section{Variability}

The analysis of mean, range, various genetic variability parameters like genotypic coefficient of variance, phenotypic coefficient of variance, heritability, genetic advance and 
genetic advance mean for different traits (Table 2) revealed that, the large differences in mean values for most of the traits were observed. Plant height ranged from 118.18 to $383.3 \mathrm{~cm}$, grain yield 38.76 to $478.46 \mathrm{~g}$, number of nodes per plant 20.60 to 292.8 , flag leaf area 12.09 to $130.49 \mathrm{~cm}^{2}$, days to fifty percent flowering 37 to $74 \mathrm{~d}$, spike length 9.87 to $58.7 \mathrm{~cm}$, peduncle length 3.34 to $46.82 \mathrm{~cm}$, flag leaf length 9.34 to $40.98 \mathrm{~cm}$, seed weight per spike 6.69 to $40.09 \mathrm{~g}, 1000$ grain weight 1.88 to $20.79 \mathrm{~g}$, number of tillers per plant 3 to 18.8 , number of productive tillers per plant 3 to 18.8 and flag leaf width 1.32 to $4.90 \mathrm{~cm}$.

According to Deshmukh et al., (1986) genotypic coefficient of variation (GCV \%) and phenotypic coefficient of variance (PCV\%) values greater than $20 \%$ are considered as high, whereas values less than $10 \%$ are regarded as low, and values between 10 and 20 considered to be medium. The estimated GCV \% ranged from 12.03 for days to $50 \%$ flowering to 57.71 for grain yield and the corresponding values for PCV\% were respectively 14.08 to 57.91 . In the present analysis, high values of PCV and GCV were obtained for the traits like grain yield, flag leaf area, number of nodes per plant, peduncle length, seed weight per spike, number of productive tillers, number of tillers per plant, spike length, 1000 grain weight, flag leaf length, flag leaf width and plant height. These results were similar to the earlier studies reported in Pearl millet by several workers Kumar, Ravindra, et al., (2020), Priyanka et al., (2019) for 1000 grain weight, Dapke et al., (2014) for flag leaf area and seed weight per spike, Vinodhana et al., (2013) for number of tillers per plant, Lakshmana et al., (2009) for spike length, plant height and number of productive tillers. Days to $50 \%$ flowering had moderately high PCV and GCV values. Contrast result also reported by Sharma et al., (2018) as days to $50 \%$ flowering had moderately high PCV and GCV.

According to Singh (1985), heritability values greater than $80 \%$ are very high, values from 40 to 59 are medium and values less than $40 \%$ are low. The very high heritability (broad Sense) values were observed for grain yield, seed weight per spike, plant height, number of nodes per plant, 1000 grain weight, number of productive tillers per plant, flag leaf width, flag leaf length, spike length, flag leaf area, number of tillers per plant. Days to $50 \%$ flowering and peduncle length had moderately high heritability. These results were confirmed by previous findings of Dapke et al., (2014) for flag leaf area and seed weight per spike, Sankar et al., (2013) for grain yield, number of nodes per plant, number of productive tillers and 1000 grain weight. Vetriventhan and Nirmalakumari (2007) for number of tillers per plant, spike length, plant height and days to $50 \%$ flowering. Heritability was conjunction with genetic advance would give a more reliable selection index value. The traits that have high heritability coupled with high genetic advance estimates were grain yield, plant height, number of nodes per plant, flag leaf area. High variability and heritability coupled with greater genetic advance indicated greater role of additive gene action in genetic control of the given traits. High heritability coupled with high genetic advance of these traits were similar to earlier results of Singh et al., (2014), Irshad-ul-Haq et al., (2015) and Basavaraj et al., (2017).

Johnson et al., (1955) classified genetic advance mean values from 0 to $10 \%$ as low, 10 to $20 \%$ as moderately high and 20 and above as high. The expected genetic advance mean was high for grain yield, plant height, days to $50 \%$ flowering, peduncle length, number of nodes per plant, flag leaf length, flag leaf width, flag leaf area, number of 
tillers per plant, number of productive tillers, spike length, seed weight per spike and test grain weight. This results were in concordance with genetic advance mean value reports of Dhedhi et al., (2016) for days to $50 \%$ flowering, plant height, grain yield, Singh, Yadav, et al., (2015) for number of nodes per plant, Sathya et al., (2014) for number of productive tillers, 1000 grain weight, seed weight per spike and Vidyadhar et al., (2007) for number of tillers per plant. The traits like grain yield, seed weight per spike, number of productive tillers, flag leaf area, number of nodes per plant revealed greatest variability parameters, and considered highly variable in Pearl millet.

\section{Correlation}

Association of plant characters with grain yield assumes a special importance in determining as to which traits, the selection should be applied to ultimately obtain high yielding hybrids. Genotypic correlation coefficient between all possible characters were presented in Table 3 and Fig. 1.

It was observed that the characters viz., seed weight per spike (0.70), spike length (0.69), test grain weight (0.56), number of productive tillers (0.53), number of tillers per plant $(0.49)$, peduncle length (0.42) exhibited highly significant positive correlation with grain yield. These traits were important yield determinant characters due to their positive and highly significant correlations with grain yield. These results were accordance to previous reports of Pear millet research workers findings of Kumawat et al., (2019) for number of productive tillers, Singh and Chhabra (2018) for seed weight per spike, Singh et al., (2018) and Bhasker et al., (2017) for 1000 grain weight, Singh, Sharma, et al., (2015) for spike length and Izge et al., (2006) for number of tillers per plant. However, grain yield revealed non-significant positive correlation with other characters like plant height (0.23), number of nodes per plant (0.21), flag leaf length (0.16), days to $50 \%$ flowering (0.10), and flag leaf area (0.07). But flag leaf width (-0.02) exhibited nonsignificant negative correlation with grain yield. Grain yield also showed non-significant correlation with these traits similar to findings of Shobha et al., (2019) for days to $50 \%$ flowering, Dapke et al., (2014) for flag tleaf area, Kumari et al., (2013) for plant height Sankar et al., (2013) for number of nodes per plant.

From the inter-correlation studies, it was observed that number of productive tillers had positive significant correlation with number of tillers per plant (0.90), number of nodes per plant (0.62), grain yield (0.53). These results were similar to findings of Nehra et al., (2017) for number of nodes per plant, Yahaya (2015) for number of tillers per plant and Arulselvi et al., (2008) for grain yield.

Seed weight per spike exhibited positive significant correlation with spike length $(0.70)$, grain yield $(0.70)$ and test grain weight (0.73). These results were accordance with findings of Subbulakshmi et al., (2018) for grain yield and 1000 grain weight, Talawar et al., (2017) for spike length. Correlation of number of productive tillers with number of tillers per plant (0.90) was positive and highly significant when compared to other biometrical traits indicating that it is possible to achieve a significant improvement in both the traits depending upon the intensity of linkage between the two traits. Contrast result was reported by Bikash et al., (2013).Thus, selection for lengthier spike with increased seed weight per spike will be significant for the improvement of grain yield in pearl millet in the material under study. 
Table.1 The experimental material consisted of 50 pearl millet genotypes collected from ICRISAT, Hyderabad

\begin{tabular}{|c|c|c|c|}
\hline S.No & Genotypes & S.No & Genotypes \\
\hline 1 & IP3080 & 26 & IP15320 \\
\hline 2 & IP3476 & 27 & IP15321 \\
\hline 3 & IP3604 & 28 & IP15322 \\
\hline 4 & IP3613 & 29 & IP15341 \\
\hline 5 & IP3616 & 30 & IP15342 \\
\hline 6 & IP3625 & 31 & IP15343 \\
\hline 7 & IP3627 & 32 & IP15344 \\
\hline 8 & IP3628 & 33 & IP15348 \\
\hline 9 & IP3636 & 34 & IP15351 \\
\hline 10 & IP3645 & 35 & IP15369 \\
\hline 11 & IP3663 & 36 & IP15710 \\
\hline 12 & IP3665 & 37 & IP17428 \\
\hline 13 & IP5836 & 38 & IP20273 \\
\hline 14 & IP8327 & 39 & IP20339 \\
\hline 15 & IP10437 & 40 & IP20346 \\
\hline 16 & IP11839 & 41 & IP20347 \\
\hline 17 & IP11840 & 42 & IP20348 \\
\hline 18 & IP15257 & 43 & IP20350 \\
\hline 19 & IP15285 & 44 & IP20379 \\
\hline 20 & IP15288 & 45 & IP20539 \\
\hline 21 & IP15290 & 46 & IP20540 \\
\hline 22 & IP15301 & 47 & IP20585 \\
\hline 23 & IP15302 & 48 & IP21226 \\
\hline 24 & IP15306 & 49 & PT4806 \\
\hline 25 & IP15307 & 50 & PT4181 \\
\hline
\end{tabular}


Int.J.Curr.Microbiol.App.Sci (2020) 9(6): 3247-3259

Table.2 Mean, range and other important variability parameters for different characters in Pearl millet

\begin{tabular}{|c|c|c|c|c|c|c|c|c|}
\hline \multirow[t]{2}{*}{ Traits } & \multirow[t]{2}{*}{ Mean } & Range & Range & \multirow[t]{2}{*}{ PCV } & \multirow[t]{2}{*}{ GCV } & \multirow[t]{2}{*}{ H (\%) } & \multirow[t]{2}{*}{ GA } & \multirow[t]{2}{*}{ GAM (\%) } \\
\hline & & Min & Max & & & & & \\
\hline DFF & 57.19 & 37.00 & 74.00 & 14.08 & 12.03 & 72.96 & 12.11 & 21.17 \\
\hline PH & 208.11 & 118.18 & 383.30 & 28.64 & 28.48 & 98.86 & 121.40 & 58.34 \\
\hline PL & 17.26 & 3.34 & 46.82 & 54.03 & 42.37 & 61.49 & 11.82 & 68.44 \\
\hline NNPP & 87.42 & 20.60 & 292.80 & 50.89 & 50.29 & 97.66 & 89.50 & 102.37 \\
\hline FLL & 24.21 & 9.34 & 40.98 & 31.32 & 30.19 & 92.94 & 14.51 & 59.96 \\
\hline FLW & 2.78 & 1.32 & 4.90 & 30.31 & 29.22 & 92.96 & 1.61 & 58.04 \\
\hline FLA & 48.20 & 12.09 & 130.49 & 52.04 & 50.03 & 92.44 & 47.76 & 99.09 \\
\hline NTPP & 9.54 & 3.00 & 18.80 & 42.51 & 39.35 & 85.70 & 7.16 & 75.05 \\
\hline NPT & 9.01 & 3.00 & 18.80 & 41.44 & 40.13 & 93.76 & 7.21 & 80.05 \\
\hline SL & 22.25 & 9.87 & 58.70 & 33.56 & 32.33 & 92.83 & 14.28 & 64.17 \\
\hline SWS & 14.04 & 6.69 & 40.09 & 41.78 & 40.88 & 95.75 & 11.57 & 82.40 \\
\hline TGW & 9.68 & 1.88 & 20.79 & 31.71 & 31.10 & 96.18 & 6.08 & 62.83 \\
\hline GY & 122.15 & 38.76 & 478.46 & 57.91 & 57.71 & 99.32 & 144.73 & 118.48 \\
\hline
\end{tabular}


Table.3 Genotypic correlation for yield and yield contributing traits in Pearl millet

\begin{tabular}{|c|c|c|c|c|c|c|c|c|c|c|c|c|c|}
\hline Traits & DFF & PH & PL & NNPP & FLL & FLW & FLA & NTPP & NPT & SL & SWS & TGW & GY \\
\hline DFF & $* *$ & 0.135 & -0.044 & 0.007 & $0.345 *$ & 0.125 & 0.270 & 0.045 & -0.108 & 0.222 & 0.208 & $0.356^{*}$ & 0.106 \\
\hline PH & & $* *$ & $0.506 * *$ & 0.255 & -0.061 & 0.072 & 0.047 & 0.170 & 0.179 & 0.156 & 0.107 & 0.061 & 0.238 \\
\hline PL & & & $* *$ & -0.001 & -0.054 & 0.010 & 0.019 & 0.123 & 0.229 & 0.241 & 0.263 & 0.192 & $0.423 * *$ \\
\hline NNPP & & & & $* *$ & -0.052 & -0.195 & -0.143 & $0.692 * *$ & $0.628 * *$ & 0.089 & -0.246 & -0.145 & 0.210 \\
\hline FLL & & & & & $* *$ & $0.643 * *$ & $0.887 * *$ & 0.036 & -0.097 & 0.269 & 0.240 & $0.309 *$ & 0.165 \\
\hline FLW & & & & & & $* *$ & $0.903 * *$ & -0.065 & -0.212 & 0.165 & 0.111 & 0.267 & -0.029 \\
\hline FLA & & & & & & & $* *$ & -0.019 & -0.159 & 0.208 & 0.177 & $0.320 *$ & 0.074 \\
\hline NTPP & & & & & & & & $* *$ & $0.907 * *$ & 0.174 & -0.134 & 0.055 & $0.493 * *$ \\
\hline NPT & & & & & & & & & $* *$ & 0.101 & -0.174 & -0.066 & $0.534 * *$ \\
\hline SL & & & & & & & & & & $* *$ & $0.702 * *$ & $0.536 * *$ & $0.697 * *$ \\
\hline SWS & & & & & & & & & & & $* *$ & $0.735 * *$ & $0.706 * *$ \\
\hline TGW & & & & & & & & & & & & $* *$ & $0.563 * *$ \\
\hline GY & & & & & & & & & & & & & $* *$ \\
\hline
\end{tabular}

** Significant at 1 percent level; * Significant at 5 percent level

$\mathrm{DFF}=$ Days to $50 \%$ flowering, $\mathrm{PH}=$ Plant height, $\mathrm{PL}=$ Peduncle length, NNPP=Number of nodes per plant, FLL=Flag leaf length, FLW=Flag leaf width, FLA=Flag leaf area, NTPP=Number of tillers per plant, NPT=Number of productive tillers per plant, $S L=S p i k e ~ l e n g t h, S W S=S e e d$ weight per spike, TGW=Test grain weight, GY=Grain yield 
Table.4 Path co-efficient analysis for yield and yield contributing traits in Pearl millet

\begin{tabular}{|c|c|c|c|c|c|c|c|c|c|c|c|c|c|}
\hline Traits & DFF & PH & PL & NNPP & FLL & FLW & FLA & NTPP & NPT & SL & SWS & TGW & GY \\
\hline DFF & -0.0135 & 0.0017 & -0.0001 & -0.0001 & -0.0199 & -0.0182 & 0.0569 & -0.0027 & -0.0761 & 0.0299 & 0.1455 & 0.0043 & 0.1056 \\
\hline PH & 8 & 2 & 0.02 & 9 & 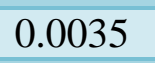 & -( & 98 & 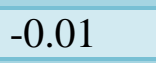 & 56 & 0208 & 42 & & 2376 \\
\hline PL & 0005 & 0.0067 & 0.0399 & 0.0004 & 0.003 & -0.0014 & 0.004 & -0.0076 & 0.1605 & 0.0324 & 0.1823 & 23 & $0.423 * *$ \\
\hline NNPF & -0.0008 & 0.0033 & -0.0005 & -0.0 & 0.003 & 0.0282 & -0.0301 & -0.0431 & 0.4402 & 0.0119 & 702 & -0. & 0.2100 \\
\hline FLL & -0.0046 & -0.0008 & -0.0021 & 0.0 & -0.0577 & -0.0932 & 0.1865 & & -0.0683 & 0.0361 & 62 & 37 & 0.1653 \\
\hline FLW & -0.0017 & 0.0009 & 0.0004 & 0.0 & -0.0 & -0 . & 0.1901 & 0.004 & 489 & 0.0221 & & & -0.0291 \\
\hline FLA & -0.0036 & 0.0006 & 0.0007 & 0.0044 & -0.0511 & -0.1 & 0.2104 & 0.0012 & -0.1114 & 0.0278 & 0.1224 & 0.0039 & 0.0745 \\
\hline NTPP & -0.0006 & 0.0022 & 0.0049 & -0.0216 & -0.0021 & 0.0094 & -0.004 & -0.0623 & 0.6356 & 0.0234 & -0.0929 & 0.0006 & $0.493 * *$ \\
\hline NPT & 0.0014 & 0.0023 & 0.0091 & -0.0196 & 0.0056 & 0.0308 & -0.0334 & -0.0565 & 0.7012 & 0.0135 & -0.1202 & -0.0008 & $0.534 * *$ \\
\hline SL & -0.03 & 0.0002 & 0.0096 & -0.0027 & -0.0155 & -0.0239 & 0.0436 & -0.0108 & 0.0707 & 0.1342 & 0.4863 & 0.0065 & $0.697 * *$ \\
\hline SWS & -0.0028 & 0.0014 & 0.0105 & 0.0077 & -0.0138 & -0.016 & 0.0372 & 0.0083 & -0.1217 & 0.0943 & 0.6923 & 0.0089 & $0.706^{* * *}$ \\
\hline TGW & -0.0048 & 0.0008 & 0.0076 & 0.0045 & -0.0178 & -0.0386 & 0.0673 & -0.0034 & -0.0462 & 0.0719 & 0.509 & 0.012 & $0.563 * *$ \\
\hline
\end{tabular}

(Residual effect $=0.39$ ) $\mathrm{DFF}=$ Days to $50 \%$ flowering, $\mathrm{PH}=$ Plant height, $\mathrm{PL}=$ Peduncle length, NNPP=Number of nodes per plant, FLL=Flag leaf length, FLW=Flag leaf width, FLA=Flag leaf area, NTPP=Number of tillers per plant, NPT=Number of productive tillers per plant, $\mathrm{SL}=$ Spike length, $\mathrm{SWS}=$ Seed weight per spike, TGW=Test grain weight, GY=Grain yield 
Figure.1 Genotypic correlation for yield and yield contributing traits in Pearl millet

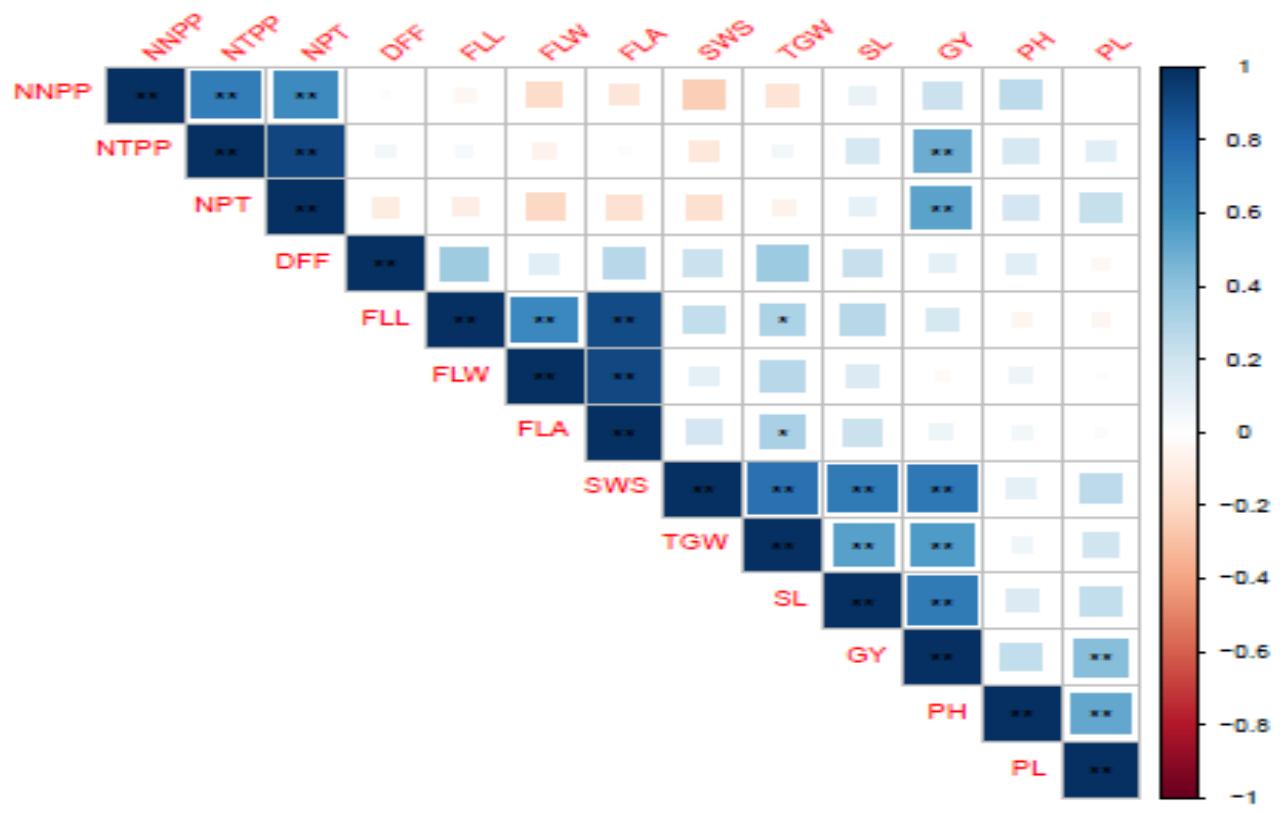

** Significant at 1 percent level; * Significant at 5 percent level

Figure.2 Path co-efficient analysis for yield and yield contributing traits in Pearl millet

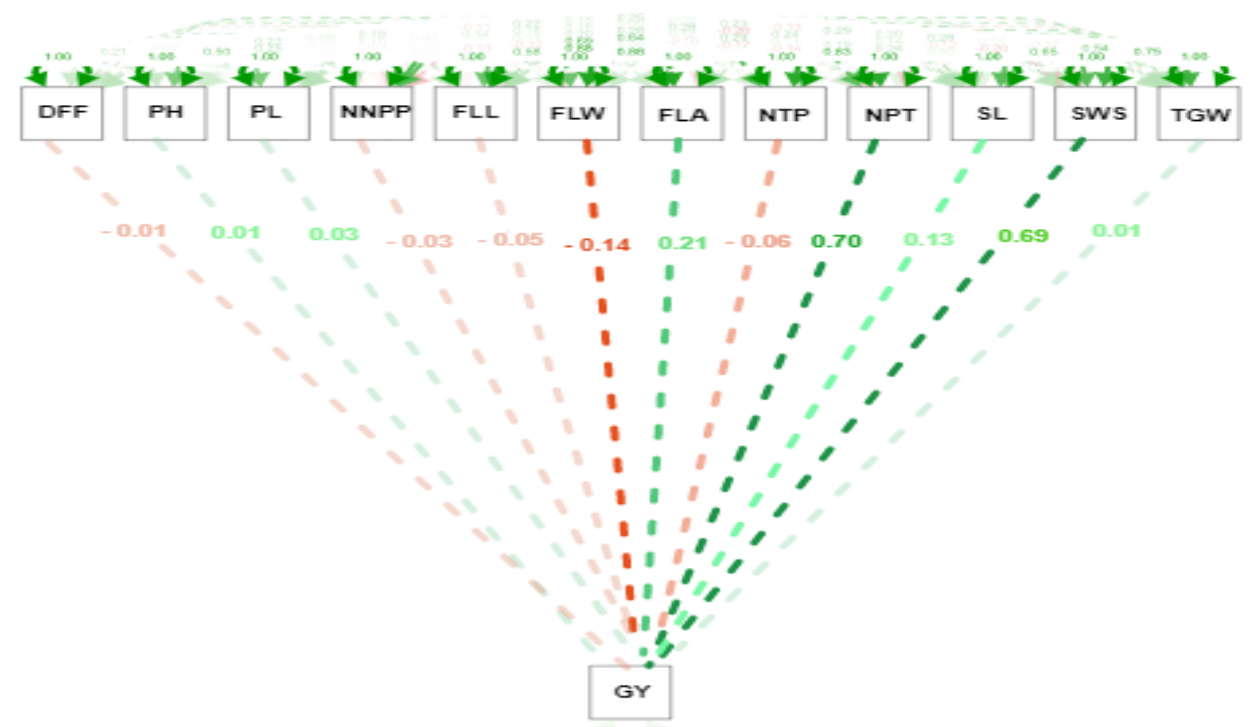

$\mathrm{DFF}=$ Days to $50 \%$ flowering, $\mathrm{PH}=\mathrm{Plant}$ height, $\mathrm{PL}=$ Peduncle length, NNPP=Number of nodes per plant, FLL=Flag leaf length, FLW=Flag leaf width, FLA=Flag leaf area, NTPP=Number of tillers per plant, NPT=Number of productive tillers per plant, $\mathrm{SL}=$ Spike length, $\mathrm{SWS}=$ Seed weight per spike, TGW=Test grain weight, GY=Grain yield. 


\section{Path analysis}

Path analysis is a statistical methodology used to separate overall effect into direct and indirect effect. The values regarding the path analysis are given in Table 4 and Fig 2. The grain yield had positive high direct effect with number of productive tillers per plant and seed weight per spike. This result was similar to findings of Abuali et al., (2012). Flag leaf area on grain yield had positive moderate direct effect. These results revealed true relationship of these characters with the grain yield. Hence, direct selection of these traits could be rewarding for the improvement of grain yield in pearl millet. Plant height, peduncle length, spike length, 1000 grain weight had very low positive direct effect with grain yield. These results were similar to findings of Kumar, Sanadya, et al., (2020) for 1000 grain weight, Kumar et al., (2014) for spike length and Chaudhry et al., (2003) for plant height. Hence, direct selection of these traits do not have any impact on grain yield improvement. Grain yield had negative direct effect with traits like days to $50 \%$ flowering, number of nodes per plant, flag leaf length, flag leaf width, number of tillers per plant. These results were similar to findings of Kumar et al., (2014) for days to 50\% flowering and number of nodes per plant. The high direct effect of number of productive tillers, seed weight per spike appeared to be the main factors for their strong association with grain yield per plant. Hence, this investigation suggested that number of productive tillers, seed weight per spike should be given maximum consideration as the appropriate selection indices in breeding for dual purpose Pearl millet hybrids.

Number of nodes per plant, number of tillers per plant showed highly positive indirect effect on grain yield through number of productive tillers. Spike length, plant height, peduncle length had low positive indirect effect with grain yield through number of productive tillers. Grain yield had negative indirect effect with traits like days to $50 \%$ flowering, flag leaf length, flag leaf width, flag leaf area, seed weight per spike and test grain weight. These indirect effect results were similar to findings of (Subbulakshmi et al., 2018) and Govindaraj and Selvi (2012). Based on the correlation and path analysis the traits $v i z$. , spike length, seed weight per spike, number of productive tillers per plant and number of nodes per plant is responsible for the grain yield improvement in Pearl millet.

\section{References}

Abuali, Atif Ibrahim, Awadalla Abdalla Abdelmulla, and Atif Elsadig Idris. 2012. "Character association and path analysis in pearl millet (Pennisetum glaucum L.)." Journal of Experimental Agriculture International 2 (3):370-381.

Arulselvi, S., K. Mohanasundaram, and B. Selvi. 2008. "Correlation and path analysis for grain yield and its components in pearl millet (Pennisetum glaucum (L.) R. Br.)." Madras Agricultural Journal 95 (7-12):311-314.

Basavaraj, P. S., B. D. Biradar, and G. M. Sajjanar. 2017. "Genetic variability studies for quantitative traits of restorer (R) Lines in Pearl millet [Pennisetum glaucum (L.) R. Br.]." International Journal of Current Microbiology and Appiled Sciences 6 (8):3353-3358.

Bhasker, K., D. Shashibhushan, K. Murali Krishna, and M. H. V. Bhave. 2017. "Correlation and path analysis for grain yield and it components in Pearl Millet [Pennisetum glaucum (L). R. Br.]." Bulletin of Environment, Pharmacology and Life Sciences 6 (1):104-106.

Bikash, Abhay, I. S. Yadav, and R. K. Arya. 2013. "Studies on variability, correlation and path analysis in pearl millet." Forage Research 39 (3):134- 
139.

Chaudhry, Muhammad Hussain, Ghulam Mahboob Subhani, Muhammad Saleem Shaheen, and Usman Saleem. 2003. "Correlation and path coefficients analysis in pearl millet (Pennisetum americanum L.)." Pakistan Journal of Biological Sciences 6 (6):597-600.

Dapke, J. S., D. S. Shah, G. N. Pawar, V. M. Dhembre, and Mithlesh Kumar. 2014. "Genetic variability and character association over environment in pearl millet [Pennisetum glaucum (L.) R. Br.] under dryland conditions of Gujarat." The Bioscan 9 (2):863-867.

Deshmukh, S. N., M. S. Basu, and P. S. Reddy. 1986. "Genetic variability, character association and path coefficients of quantitative traits in Virginia bunch varieties of groundnut." Indian Journal of Agricultural Sciences 56:816-821(812).

Dhedhi, K. K., V. V. Ansodariya, N. N. Chaudhari, J. M. Sanghani, and J. S. Sorathiya. 2016. "Genetic Variability and Correlation Coefficient for Fodder Yield and its Components in Forage Pearl Millet Hybrids under Rainfed Conditions of Gujarat." International Journal of Bio-resource and Stress Management 7 (5):970-977.

Govindaraj, M., and B. Selvi. 2012. "Path coefficient analysis in local pearl millet germplasm for grain minerals and agronomic characters." Agricultural Science Digest-A Research Journal 32 (2):128-132.

Irshad-ul-Haq, Muhammad, Saeeda Khanum, Muhammad Siddique, and Naveed Kamal. 2015. "Correlation and heritability studies in pearl millet." International Journal of Biology and Biotechnology (Pakistan) 12 (1):81-83.

Izge, A. U., A. M. Kadams, and D. T. Gungula. 2006. "Studies on character association and path analysis of certain quantitative characters among parental lines of pearl millet (Pennisetum glaucum) and their F1 hybrids in a diallel cross." African Journal of Agricultural Research 1 (5):194-198.

Johnson, Herbert W., H. F. Robinson, and R.

E. Comstock. 1955. "Estimates of genetic and environmental variability in soybeans 1." Agronomy journal 47 (7):314-318.

Kumar, Ravindra, Sanjay Kumar Sanadya, Anil Kumar, Mukesh Kumar, and Devendra Chandeland P. C. Yadav. 2020. "Estimation of correlation coefficient and path analysis in hybrids of pearl millet [Pennisetum glaucum (L.) R. Br.]." International Journal of Chemical Studies 8 (1):1254-1256.

Kumar, R., S. Harish, M. S. Dalal, V. Malik, Devvart, L. K. Chugh, P. Gargand, and Raj K. 2014. "Studies on variability, correlation and path analysis in pearl millet [Pennisetum glaucum (L.) R. Br.] genotypes." Forage Research 40 (3):163-167.

Kumar, Ravindra, Sanjay Kumar Sanadya, Anil Kumar, Mukesh Kumar, and Devendra Chandeland P. C. Yadav. 2020. "Estimation of correlation coefficient and path analysis in hybrids of pearl millet [Pennisetum glaucum (L.) R. Br.]." International Journal of Chemical Studies 8 (1):1254-1256.

Kumari, Mamta, D. K. Garg, R. S. Saini, and B. L. Jat. 2013. "Genetic variability and correlation coefficient in pearl millet [Pennisetum glaucum (L.) R. Br. Emend Stuntz]." Forage Research 39:83-87.

Kumawat, Kana Ram, N. K. Sharma, and Nemichand Sharma. 2019. "Genetic variability and character association analysis in pearl millet single cross hybrids under dry conditions of Rajasthan." Electronic Journal of Plant Breeding 10 (3):1067-1070.

Lakshmana, D., B. D. Biradar, and R. L. 
Ravikumar. 2009. "Genetic variability studies for quantitative traits in a pool of restorers and maintainers lines of pearl millet (Pennisetum glaucum (L.))." Karnataka Journal of Agricultural Sciences 22 (4):881-882.

Nehra, Mamta, M. Kumar, J. Kaushik, D. Vart, R. K. Sharma, and M. S. Punia. 2017. "Genetic Divergence, Character Association and Path Coefficient Analysis for Yield Attributing Traits in Pearl Millet [Pennisetum Glaucum (L.) R. Br] Inbreds." Chemical Science Review and Letters 6 (21):2278-6783.

Priyanka, V., P. Shanthi, D. M. Reddy, and Ravindra Reddy, B. 2019. "Genetic variability studies on Yield, Physiological and Nutritional Traits in Pearl Millet [Pennisetum glaucum (L.) R. Br.]." International Journal of Current Microbiology and Appiled Sciences 9 (7):501-508. doi: 10.20546/ijcmas.2019.807.061.

Sankar, S. Mukesh, C. Tara Satyavathi, Madan Pal Singh, C. Bharadwaj, S. P. Singh, and S. Barthakur. 2013. "Genetic variability and association studies in pearl millet for grain yield and high temperature stress tolerance." Indian Journal of Dryland Agricultural Research and Development 28 (2):7176.

Sathya, M., P. Sumathi, N. Senthil, S. Vellaikumar, and A. John Joel. 2014. "Genetic studies for yield and its component traits in RIL population of pearl millet (Pennisetum glaucum [L.] R. Br.)." Electronic Journal of Plant Breeding 5 (2):322-326.

Sharma, Bunty, Laxman Kumar Chugh, Ram Kumar Sheoran, Vivek K. Singh, and Meenakshi Sood. 2018. "Study on genetic variability, heritability and correlation in pearl millets germplasm." Journal of Pharmacognosy and Phytochemistry 7 (6):1983-1987.
Shobha, Rani, T., S. C. V. Kumar, S. Maheswaramma, M. Parimal, A. G. Kumar, and K. Sravanthi. 2019. "Selection criteria for grain yield in pearl millet (Pennisetum glaucam L.) in association with yield contributing traits." International Journal of Pure \& Applied Bioscience 7 (3):257-262. doi: 10.18782/2320-7051.7471.

Singh, B. D. 1985. Principles and methods of horticultural Breeding, Plant breeding. New delhi: Kalyani publishers.

Singh, Bhuri, K. C. Sharma, and H. K. Meena. 2015. "Character association and path analysis of certain quantitative characters among parental lines and their hybrids in pearl millets." Agricultural Science Digest-A Research Journal 35 (2):121-125.

Singh, Jagdeep, and Ashok Kumar Chhabra. 2018. "Genetic Variability and Character Association in Advance Inbred Lines of Pearl Millet Under Optimal and Drought Condition." Ekin Journal of Crop Breeding and Genetics 4 (2):45-51.

Singh, O. V., R. Gowthami, K. Singh, and N. Shekhawat. 2018. "Assessment of InterCharacters Association in the Germplasm of Pearl Millet [Pennisetum glaucum (L.) R. Br.] over five years in hot arid climate of Rajasthan, India." International Journal of Current Microbiology and Appiled Sciences 7 (1):3133-3149. doi: 10.20546/ijcmas.2018.701.372.

Singh, Satbeer, Y. P. Yadav, H. P. Yadav, D. E. V. Vart, and Niketa Yadav. 2014. "Studies on Genetic variability and trait association for grain yield and its components in pearl millet [Pennisetum glaucum (L.) R. BR.]." Forage Research 40 (2):91-94.

Singh, Satbeer, Y. P. Yadav, H. P. Yadav, Dev Vart, and Niketa Yadav. 2015. "Genetic variability, character 
association and path analysis among yield contributing traits in pearl millet [Pennisetum glaucum (L.) R. Br.]." BIOINFOLET-A Quarterly Journal of Life Sciences 12 (3a):640-644.

Srivastava, Rakesh K., Ram B. Singh, B. Srikanth, C. Tara Satyavathi, Rattan Yadav, and Rajeev Gupta. 2019. "Genome-wide association studies (GWAS) and genomic selection (GS) in pearl millet: advances and prospects." Frontiers in Genetics 10:1389.

Subbulakshmi, K., P. Sumathi, and C. Babu. 2018. "Association Study of Grain Yield and Nutritional Quality Traits in Pearl Millet [Pennisetum glaucum (L.) R. Br.] Hybrids." International Journal of Current Microbiology and Applied Sciences, 7(10): 2035-2039.

Talawar, A. M., G. Girish, A. S. Channabasavanna, and M. S. Kitturmath. 2017. "Studies on genetic variability, correlation and path analysis in pearl millet (Pennisetum glaucum L.) germplasm lines." Agricultural Science Digest-A Research Journal 37 (1):7577.

Ullah, Asmat, Nasrin Salehnia, Sohrab Kolsoumi, Ashfaq Ahmad, and Tasneem Khaliq. 2018. "Prediction of effective climate change indicators using statistical downscaling approach and impact assessment on pearl millet (Pennisetum glaucum L.) yield through Genetic Algorithm in Punjab, Pakistan." Ecological Indicators 90:569-576.

Vetriventhan, M., and A. Nirmalakumari. 2007. "Studies on variability parameters in pearl millet (Pennisetum glaucum (L.) R. Br.)." Madras Agricultural Journal 94 (1/6):118-120.

Vidyadhar, B., Pooran Chand, I. Swanalatha Devi, M. Reddy, and D. Ramachandraiah. 2007. "Genetic variability and character association in pearl millet \{Pennisetum glaucum (L.) R. Br. $\}$ and their implications in selection." Indian Journal of Agricultural Research 41 (2):150-153.

Vinodhana, N. K., P. Sumathi, and M. Sathya. 2013. "Genetic variability and interrelationship among morpho-economic traits of pearl millet (Pennisetum glaucum (L.) r. Br.,) and their implications in selection." International journal of plant, animal and environmental sciences 3 (2):145-149.

Yahaya, Yakubu. 2015. "Correlation and Heritability in Pearl Millet (Pennisetum glaucum (L) R. Br." African Journal of Agronomy 3 (3):257-258.

\section{How to cite this article:}

Annamalai, R., N. Aananthi, M. Arumugam Pillai and Leninraja, D. 2020. Assessment of Variability and Character Association in Pearl Millet [Pennisetum glaucum (L.) R.Br.]. Int.J.Curr.Microbiol.App.Sci. 9(06): 3247-3259. doi: https://doi.org/10.20546/ijcmas.2020.906.388 